This is an author produced version of a paper published in Journal of Family Business Management.

This paper has been peer-reviewed but may not include the final publisher proof-corrections or pagination.

Citation for the published paper:

Andersson, Elias; Lundqvist, Peter. (2016) Gendered time in Swedish family farming - operationalising an agrarian typology using the Swedish Farm Accountancy Data Network. Journal of Family Business Management. Volume: 6, Number: 3, pp 310-329.

http://dx.doi.org/10.1108/JFBM-07-2015-0023.

Access to the published version may require journal subscription.

Published with permission from: Emerald.

Epsilon Open Archive http://epsilon.slu.se 


\title{
Gendered time in Swedish family farming:
}

Operationalising an agrarian typology using the Swedish Farm Accountancy Data Network Elias Andersson \& Peter Lundqvist

\begin{abstract}
The agricultural sector has undergone extensive changes in the 20-30 years since the peak academic debate on family farming. The size of the CAP component in the EU budget emphasises the clear political and economic implications of agriculture. This study examined the concept of the family farm and its utilisation and diversity in the current Swedish agricultural sector from a gender perspective, using empirical data from the Farm Accountancy Data Network (FADN). The study operationalised a situated agrarian typology and examined the gendered position and temporalities of family farms in Sweden, based on patterns of labour use. The results revealed a workable, fruitful typology of the agrarian structure suitable for future comparative studies and also demonstrated the gendered time in the farm labour process, the different temporalities involved and their interconnection between gender, family and various spheres.

This study contributes to the understanding of spatial-temporal relations of family farm business and organisation in general and in Sweden particularly. It also provides the basis for developing rural and agricultural policies and their goals and practices.

Keywords: family farm, gender, labour, temporality, FADN
\end{abstract}

\section{INTRODUCTION}

The agricultural sector has undergone extensive changes since the height of the academic intensive debate on the concept of family farming during the 1980s-1990s. Since the late 1980s, the number of Swedish farm businesses has dropped by one-third, while average farm size has increased. The $9 \%$ of largest farms with more than 100 ha arable land hold 
$45 \%$ of the total arable area in Sweden (SCB, 2011b). This restructuring process, together with the rationalisation and capitalisation of farm production, has contributed to diversification of farming within and between farms. It is also driving the increasing gap between large farms and part-time farms or "sub-family farms" (Djurfeldt, 1996). The "disappearing middle" is, as Buttel (1983) notes, "an empirical trend rather than a completed process" and does not imply a growing prevalence of large, capitalist farms, as is often assumed (Djurfeldt and Gooch, 2002). However, Swedish agriculture comprises a large variation in climate, geography and spatial conditions, e.g. distance to urban centres, soil quality and climate, with conditions in southern Sweden being much more similar to the conditions of central Europe than those in northern Sweden. Thereby, the Swedish case contributes to the understanding of temporality in a set of specific spatial conditions, localities, ideologies and relations that differs from much of the previous research (Forsberg, 2005) (Table 1). The policy and political context of Sweden, with its long tradition of promoting gender equality, also add to this case (Ds, 2004).

\section{Sweden UK US}

\begin{tabular}{|c|c|c|c|}
\hline Number of farm businesses (thousand) & 71 & 187 & 2200 \\
\hline Share of agricultural land & $7.5 \%$ & $73.5 \%$ & $45.4 \%$ \\
\hline Average farm size (ha) & 37 & 90 & 169 \\
\hline $\begin{array}{l}\text { Percentage of GDP from agriculture (incl. } \\
\text { forestry) }\end{array}$ & $1.4 \%$ & 0.7 & $1.4 \%$ \\
\hline Change in GDP from agriculture in past 5 years & $-12.5 \%$ & 0 & $+27.3 \%$ \\
\hline $\begin{array}{l}\text { Percentage of total employed in agriculture (incl. } \\
\text { subsidiary industries) }\end{array}$ & $2.3 \%$ & $1.4 \%$ & $1.6 \%$ \\
\hline
\end{tabular}


Table 1. Comparison of agriculture in Sweden, Unitied Kingdom and United States (USDA, 2011, SJV, 2013, NS, 2013, WB, 2016, OECD, 2016), motivated by that much of the litterature and theories on family farming in Western countries is placed in the context of the UK or the US - a situation that much differ from the Swedish (Forsberg, 2005).

Today an essential amount of farm household income often comes from paid labour outside the farm, which has come to exceed farm income during recent decades (Jervell and Løyland, 1998, Kinsella et al., 2000). During the same period, the value of farm work has decreased and women's off-farm labour has been described as one of the most important changes in the farm household (Blekesaune, 1996). The value of farm work, in this labourintensive production sector, always been valued low, a vital argument in the debate on the survival of family farming (Friedmann, 1986a). Increasing levels of technological development in order to uphold the sustainable intensity of production have increased the social and economic pressure on family farms. The process of agricultural industrialisation and the power of retail food empires are introducing strong downward pressures on local and regional food production (Ploeg, 2008). Within Europe, farmers are struggling for independence and survival in a context of deprivation and dependency, driving a process of re-peasantisation together with further industrialisation and deactivation (Ploeg, 2008).

Despite early predictions (e.g. Lenin, 1946), the agricultural sector is still dominated by family-based production units (Djurfeldt and Gooch, 2002). These two factors, together with the strong male domination and control of the sector, clearly highlight the importance and value of extended research on the concept and practices of family farming. The aim of this study was to operationalise a situated agrarian typology based on Swedish Farm Accountancy Data Network (FADN) to contribute to the theoretical discussion on the concept of family farming and to analyse the temporal and gendered organisation of farm work. The empirical data permitted situated analysis of the production unit, the farm, in Swedish agrarian structure from a temporal perspective. As Bryson (2008) suggests, 
quantitative time studies are valuable for revealing certain types of time use, but the limited conceptions of time in FADN may inhibit the ability to see women's work, which needs to be explored to provide a more sophisticated understanding. The need to further engage with the concept of time within family business research has been stressed (Sharma et al., 2014). Thus, by placing the labour process and gender at the centre, the gendered relations and positions of farming were analysed and discussed.

Despite the gender equality policy aims (Ds, 2004) and various attempts to improve the situation in rural areas, e.g. by supporting women's entrepreneurship, the male domination of the sector persists (SCB, 2012), contributing to the masculinisation of farm work (Bjørkhaug and Blekesaune, 2007, Brandth, 2002). Sweden has one of the highest hourly labour costs in Europe, which highlights the issue of labour and the gap between the family farm and the labour market (Eurostat, 2012). Based on patterns of labour use in farms run by women and men in various geographical locations, this study sought to examine the identification of family farms in the structural context of Sweden. The rapid changing conditions in agriculture have created a need for the development of a situated agrarian typology in order to better understand agrarian processes, social relations and materialities. From a policy perspective, this is crucial to understand the policy problem and its implications. This study takes an empirical standpoint in the Swedish context to explore the concept of family farms in a situated dialogue with Djurfeldt (1996) and Waldenström (1996).

\section{THEORY}

\subsection{The situated family farm of Sweden}

The family farm is one of the most long-lasting social, cultural and historical phenomena in the Western world. It has stood the test of time (Whatmore, 1991) and continues to be the 
primary production unit within the agrarian sector of Sweden and Northern Europe (Djurfeldt and Gooch, 2002, Blekesaune, 1996). The persistence of Swedish family farming is situated in its particular historical and political preconditions (Flygare and Isacson, 2011). Three broader explanatory factors are listed by Bernstein (2010): 1) "obstacles" to the investment of capital in farming, 2) the interest of capital in allowing, or encouraging, the reproduction of small-scale farming, and 3) resistance by small-scale farmers to dispossession and proletarianisation.

In terms of obstacles, some of the main factors are the northern climate, with longer production time and tied up capital (Bernstein, 2010), the agrarian structure dominated by small-scale (Morell, 2011b, Flygare, 2011, Flygare and Isacson, 2011) and part-time or pluriactive farms (LSR, 1988, Djurfeldt and Gooch, 2002), the high level of family transfer of agricultural land (Ciaian et al., 2010, Morell, 2011b, SCB, 2011c) and the regulation of land acquisition (SFS, 1979). The majority of the Swedish landscape is covered with productive forest, leaving a small proportion of farm land (SKS, 2013). These conditions encourages a flow of risk downstream that is absorbed by the family farm (Ploeg, 2008). In the resistance to the influences of capital, the strong social movements of the twentieth century, with their interconnection with the political sphere, have played an important role. The labour union movement has increased the general wage levels and the influence of various farmers' organisations (Morell, 2011a, Djurfeldt, 1994). However, the producer cooperative movement has been a major factor in farmers' control of the whole production chain and decreased dependence on agribusinesses (Rydén, 2004, Flygare and Isacson, 2011).

Family-owned businesses in the Swedish economy substantially contribute to employment and GDP. Depending on criterion, in 2006, these businesses employed between one fourth and a fifth of the working population and contributed with one fifth or a sixth to the GDP. 
The level of self-employment in Sweden is about $5.6 \%$. In a long-term perspective, these shares have increased due to shifts in economic policy and deregulation (Bjuggren et al., 2011). The public sector of Sweden is relatively large (cf. Astrachan and Shanker, 2003) and Swedish economic policy has been criticized for favoring larger firms (eg. Lindbeck, 1997, Henrekson, 2005). In the rural economy, the family farm constitute to great extent the backbone in many parts of Sweden with its demand for products, services and food processing (Flygare and Isacson, 2011). The conditions for farm development and pluriactivity vary greatly in different regions and parts of the country depending on e.g. spatial, ecological and structural factors (Maskell, 2001a, 2001b).

The family's ability to provide cheap flexible labour is a crucial (Reimer, 1986, Friedmann, 1986a, Long, 1986), even more so in a Swedish case with a general high wage level and low yields. The labour process and property relations are interconnected and reproduce gender inequalities on the family farm (Friedmann, 1986a), i.e. by processes of socialisation that over time ensure men's access to property (Flygare, 2001, Lidestav, 2010, Flygare, 1999). Whether the family farm hires additional labour or family members work outside for wages, "their relations in production [the labour process] distinguish them from capitalist enterprises" (Friedmann, 1986b).

\subsection{Theoretical framework}

The academic debate on the concept of family farming reached its peak during the 1990s, when the political implications of typology were repeatedly stressed (eg. Hill, 1993, Gasson and Errington, 1993, Djurfeldt, 1996, Vogeler, 1981), emphasising that the concept "is as much ideological imagery as it is socioeconomic fact" (Bennett et al., 1982). The debate has to a limited extent continued, partly shaped by the diverse contextual development and implication of agrarian change (eg. Calus and Huylenbroeck, 2010, Pritchard et al., 2007, 
Johnsen, 2004, Gezelius, 2014, Bjørkhaug and Blekesaune, 2008, Moxnes Jervell, 1999). Its primary political base of direct implications can be found in the EU agricultural funding system, the CAP. The societal importance of preserving the family-structured agriculture has frequently been raised (Lobao and Meyer, 2001, Lyson et al., 2001, Welsh, 2009), by the European Commission (Hill, 1993) as well as in the Swedish political context (Flygare, 2008).

In the classical typological debate within academia regarding the significance of ownership (Gasson and Errington, 1993) and labour (Hill, 1993, Djurfeldt, 1996, Djurfeldt and Waldenström, 1996) in family farming, this study and it's typology, situated in the Swedish context, emphasise the importance of the relations of the agrarian labour process. A primary concern in recent decades has been the development, mechanisation and capitalisation of agricultural production, so as to reduce the need for human labour inputs. The one-man farm (Bailey, 1973) is an example of a case where the need for other family members' labour has been eliminated by a high degree of mechanisation, but where the family still controls the farm. The one-person farm is also an important concept for the social relations of farming, with the farmers work by oneself. However, a too strict interpretation of this concept runs the risk of concealing the farm work of other family member and turning it into a misnomer.

Time, as a form of exchange that goes beyond the traditional understanding of economics (e.g. Hochschild and Machung, 1989, Glucksmann, 2005) and is bought and sold, in everyday life, within a larger context than the relations of wage labour. Time constitutes an integral dimension of power in social relations and thereby may contain elements of exploitation (Glucksmann, 1998). Social relations are organised on the basis of the value of different types of time, its situation in the day and flexibility. Space and time are coconstructed in the processes of social reproduction, reinforcing the temporal and spatial 
organisation of social relations (Harvey, 1990) and underlining the premise that place matters (Pini and Leach, 2011, MacDonald et al., 2005). In farming, place, in terms of natural conditions, shapes the relationship between labour time and production time (Bernstein, 2010). Within the field of family business research, the concept of time has received limited attention, especially from both a quantitative and a structural and relational understanding (Sharma et al., 2014).

Miriam Glucksmann defines temporality as "an element of all social relationships, processes and structures, an integral aspect that is both constitutive of them and constituted by them" (Glucksmann, 2000). The aim of this concept is to denote the distinctive structure of time, in its various instances. The social processes of the family farm are a mixture of various forms of temporalities, division of labour and material and spatial relations. When examining the different form of temporalities and their interconnection in a larger context, time is a fruitful concept for understanding the gendered relations of family farm activities and organisation in the economic sphere.

\subsection{Operationalisation}

Beside their labour use criterion, Djurfeldt and Waldenström (1996) also formulate a composite criterion based on an index combining household income, household labour and the labour on the farm, where a number of other farm types are defined. However, due to details on household income and labour in their data, this criterion is less comparable to the data of this study. In their labour use criteria, Djurfeldt and Waldenström (1996) distinguish between family labour farms that are dependent/not dependent on off-farm work and those that have/have not the ability to reproduce the farm and the family (reproductive and nonreproductive). The data contained in FADN relate solely to the business activities on the farm, and therefore do not provide full information on the farm household, its finances and 
the off-farm labour by family members. Due to this lack of household data, in this study the definitions were adjusted with the production unit, the farm business, in the centre. This places the definition used in this study between those of Hill (1993) and Djurfeldt (1996). Based on the data available, four farm types were defined, including the one-person farm, based on the term "one-man mechanized farm" coined by Bailey (1973). This farm type was characterised here by its ability to provide full-time work for one family member ( 1 Annual Working Unit, AWU). The part-time farm was defined in direct relation to the labour input of less than 0.6 AWU. However, problems in drawing the exact boundaries of productive small farms can create a bias in estimates of the proportion of part-time and one-person farms. Djurfeldt and Waldenström previously defined network labour as "labour recruited through kin and community networks" (1996). In the Swedish context, the communal organisation and exchange of relief labour has a long history (Lundqvist et al., 1997). During the latter half of the 20th century, the state actually organised a system of relief labour in order to enable farmers to take a vacation and to cover absenteeism. Since the 1990s, this relief labour has mainly been organised by specialist companies or jointly by groups of farm businesses (SOU, 1995). In the present study, this type of labour was labelled network labour and was defined as hired labour inputs of up to 0.2 AWU. Two larger farm types were identified based on the dominant type of labour; family $(\mathrm{F})$ or hired (H). In terms of this index, the farm types studied were thus:

$$
\begin{array}{ll}
\text { Part-time farm }(\mathrm{PT}) & =<0.6 \mathrm{AWU} \\
\text { One-person farm }(\mathrm{OP}) & =0.6 \leq \mathrm{p} \geq 1 \mathrm{AWU} \\
\text { Family labour farm }(\mathrm{FL}) & =1 \mathrm{AWU}<\mathrm{p} ; \mathrm{F}-\mathrm{H} \geq 0 \\
\text { Labour-hiring farm }(\mathrm{LH}) & =1 \mathrm{AWU}<\mathrm{p} ; \mathrm{F}-\mathrm{H}<0
\end{array}
$$


The Blekesaune (1996) criticism of gender-blindness in the typology of Djurfeldt (1996) extends, in our view, to all three of the main definitions (Hill, 1993, Gasson and Errington, 1993). This does not necessarily disqualify them, but clearly raises an awareness of their limitations and therefore calls for theoretical supplements in this area. In this study, the concept of time and temporalities was used to increase the understanding of gendered organisation of farming and the agricultural structure. In investigating the different temporalities of the family farm, analysis of women's total labour it is vital in order to include "these dimensions of the farm labour process" that have previously been "neglected by the narrow focus on agricultural production" (Whatmore, 1991) and to devote more attention to farm- and farm household-level dynamics (Buttel, 1996). The lack of data on the division of labour at household level renders the study of gender relations more difficult from a labour process perspective. However, the unequal division of domestic labour within Swedish farm household has been documented (e.g. Flygare, 1999) and research in the neighbouring country of Norway has shown that the gender differences are larger than within non-farm households (Blekesaune and Haugen, 2002).

\section{MATERIAL AND METHODS}

The FADN was established in 1965 as a tool for collecting accountancy data from agricultural holdings in the European Union (EEC/79/65). The primary purpose of FADN is to support the creation and assessment of the CAP. FADN is the only harmonised and standardised source of data obtained from a sample of individual farms across all EU member states. When Sweden became a member of the European Union in 1995, the annual Swedish Farm Economic Survey (JEU) was harmonised and standardised to the FADN methodology, which aims to monitor, illustrate and evaluate the income and economic conditions of European farms. The database contains a sample of individual farms across all 
member states. The Swedish sample consists of about 1000 farms that are stratified by region, farm size and type of farming (EC, 2013b).

In the beginning of the twentieth century, the vast majority of Swedish farmers owned their own farm, a similar picture to that in the rest of Scandinavia and large parts of Western Europe (Morell, 2011a, Hoyle et al., 2010). The Swedish agriculture sector was largely populated by small family farms, but during the nineteenth century large estates had expanded in some areas, mainly southern valleys (Olsson, 2002, Morell and Olsson, 2010, Hansen, 2006). The importance of agriculture at national level gradually decreased in Sweden during the 20th century. Today, the agricultural sector accounts for only $0.5 \%$ of Swedish GDP. The main income-producing agricultural activities are dairy (25-30\%) and cereal production (15-20\%) (SCB, 2011a). In general, the Swedish agricultural sector is highly specialised and only about 10\% of farms can be categorised as 'mixed' (SCB, 2010). Based on the FADN definition, Swedish agriculture engages about 178000 people and about 65000 AWU, which corresponds to about $1 \%$ of total gainful employment in Sweden. One AWU corresponds to 1800 hours or more per year. The major source of labour input is the farm owner and family members, who account for almost $80 \%$ of personnel. More than $60 \%$ of those working in agriculture are men (SCB, 2010). The production enterprise/s, farm size and profitability of Swedish farms are partly dependent on their location, i.e. distance to markets and urban centres, soil quality and climate.

The farms in the FADN are not representative of all farms in Sweden and Europe, since they are required to be 'commercial' according to regulation EEC/79/65. A minimum European Size Unit (ESU) has been established based on standardised gross margins in each member state to define the commercial farm. The current study is based on data from 2008 , when the threshold was exceeded by about Swedish 27000 farms. The observations cover about $40 \%$ of the total of 72600 agricultural businesses in Sweden. However, $84 \%$ of the 
total agricultural land (UAA) and 74\% of the total agricultural labour (AWU) in Sweden are included in the sample population (EC, 2013a). In cross-referencing with data on owner gender in this study, 501 of 1025 farms in the sample were excluded due to lack of information and thus the sample used in the analysis consisted of 524 observations. The previous studies of the Swedish context (Djurfeldt and Waldenstrom, 1999, Djurfeldt and Waldenström, 1996, Djurfeldt and Gooch, 2002) use a different type of data with a lower threshold in terms of farm size. Although that the main focus of this study is to examine the contemporary agrarian structure from a gender perspective based on labour use, this makes it only possible to make general assumptions about the develop of the agrarian structure. In cross-tabulations, chi-squared tests were used to test variations between different categories, while differences between means and proportions were examined using a t test. In the analysis, the data were supported by official statistics when necessary. The operationalisation of a family farm typology in the analysis departs from a family business definition that differentiate between the managerial control and direct labour undertaken by family members (cf. Sharma, 2004).

\section{RESULTS}

The 524 farms in the samples were located in three areas of Sweden (Figure 1); the southern plains (slättbygdslän) (64.3\%), the central forest regions (skogs- och mellanbygdslän) (24.4\%) and the northern regions (län i norr) (11.3\%). The average farm size in the sample was 112.4 hectares (Table 2) and the median farm had 71.3 hectares of arable land. These figures indicate the productive focus of the data in relation to the broad farm business sector, as well as the diversity in farm size in the material. The average acreage owned in the plains and forest regions was significantly larger than in the northern regions $(\mathrm{p}<0.05)$. 


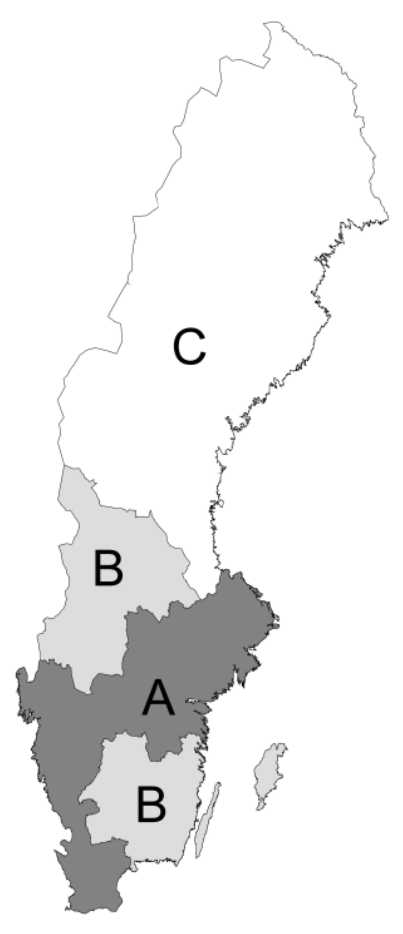

Figure 1. The three regions of Sweden (A: Southern plains, B: Middle forest regions, C: Northern regions) (EC, 2013b)

\begin{tabular}{c|cccc} 
Study area & Average area (ha) & Owned area (ha) & Rented area (ha) & $\boldsymbol{n}$ \\
\hline Plains & 119 & 56 & 63 & 337 \\
Forest & 110 & 47 & 63 & 128 \\
North & 83 & 20 & 63 & 59 \\
Total & 112 & 50 & 63 & 524
\end{tabular}

Table 2. Average arable acreage in each study region

\subsection{Farm type}

The distribution of farm types (Table 3) showed a slight shift compared with earlier studies (Djurfeldt and Waldenström, 1996, Djurfeldt, 1990), particularly in the group of labourhiring farms, the proportion of which was more than 2.5-fold larger. Although, with the lower farm size threshold of the previous studies, the hiring labour farms are not fully comparable. However, the proportion of farms that provide labour of up to one AWU (parttime and one-person farms) has remained more or less constant since the beginning of the 1990s (Djurfeldt and Waldenström, 1996). This shows that there have only been small shifts 
in the general farm structure in the past two decades, although there may have been a bias in difference in sample or adjustment to the labour-use criterion. Overall, the data clearly showed the dominance of the family labour farm in the sector. The proportion was similar to that in previous studies, thereby underling the continuing dominant position of family labour-based production. The small proportion of farms dependent on hired labour, according to the labour-use criterion, emphasises the importance and consistency of familybased farming in Sweden.

\begin{tabular}{ll}
\hline Farm type by labour-use criterion & Percentage of total \\
\hline Part-time farm & 10.1 \\
One-person farm & 30.9 \\
Family labour farm & 51.1 \\
Labour-hiring farm & 7.8 \\
\hline Total & 100
\end{tabular}

Table 3. Distribution of farm types according to the labour-use criterion

According to the Djurfeldt's criteria defined above, there is a distinction between family farms that are dependent/not dependent on hired labour. Due to lack of data on household level, this distinction could not be included in the criteria of this study. However, $31.7 \%$ of the family labour farms in the data had a hired labour input of more than 0.2 AWU and $10.1 \%$ had only an input of network labour. Thus in comparison with the results of Djurfeldt and Waldenström (1996), there was a shift in the use of hired labour within the group of family labour farms, as about $48.2 \%$ of the family labour farms in their study were dependent on hiring-in. The slight variation in the criterion could account for a small part of this difference, but it might otherwise indicate a stratification of hired labour use due to rationalisation and changing economic conditions.

In recent decades, the one-person farm, driven by technical development and rationalisation, has increased in the Swedish (Djurfeldt, 1981, Djurfeldt, 1996), as well as 
the Norwegian (Bjørkhaug and Blekesaune, 2007), agrarian structure and has proven to be more flexible in times of crisis (Djurfeldt and Gooch, 2002). Since 1991, the proportion of one-person farms has increased by 7\% (Djurfeldt and Waldenström, 1996). However, about $4 \%$ of the 162 farms in this group in our sample are to some extent dependent on hired labour and $7.4 \%$ have an input of network labour. All of these farms have one part-time worker, which means that they could be defined as two-person, part-time farms. This indicates a small bias in the labour-use criterion used in this study and the difficulties with the typology in its combination of type and size of labour input. The farm type denomination indicates mainly that one person does the primary work, within the parameters defined above. However, the farmer does $85 \%$ of the total work, while the family provides $10 \%$ of the labour input ( $7 \%$ spouse, $3 \%$ other family members). The farm organisation of the one-person farm reflects the changing economic conditions in farming and the growing service and public sector. In this process, farm wives have become expendable and can choose employment outside the farm (Bäck-Wiklund and Lindfors, 1990, Kelly and Shortall, 2002), sometimes even to subsidise the husband's farm (Djurfeldt and Waldenström, 1996). However, in previous studies $41 \%$ of one-person farms were owned and managed by a single adult (Djurfeldt, 1996). This reveals the interconnection of temporalities between different spheres and the shift in organisation of labour over time.

The agrarian structure and its composition for the four farm types identified here were linked to geographical position in Sweden. In the more productive agricultural plains region, the proportion of FL farms was smaller and that of the three other groups slightly larger in comparison with the central forest and northern regions (Figure 2). The proportion of family labour farms was significantly larger in the forest region than in the plains, while the plains had a significantly larger proportion of part-time farms $(\mathrm{p}<0.05)$, emphasising both the spatial and temporal dimension of temporality. 


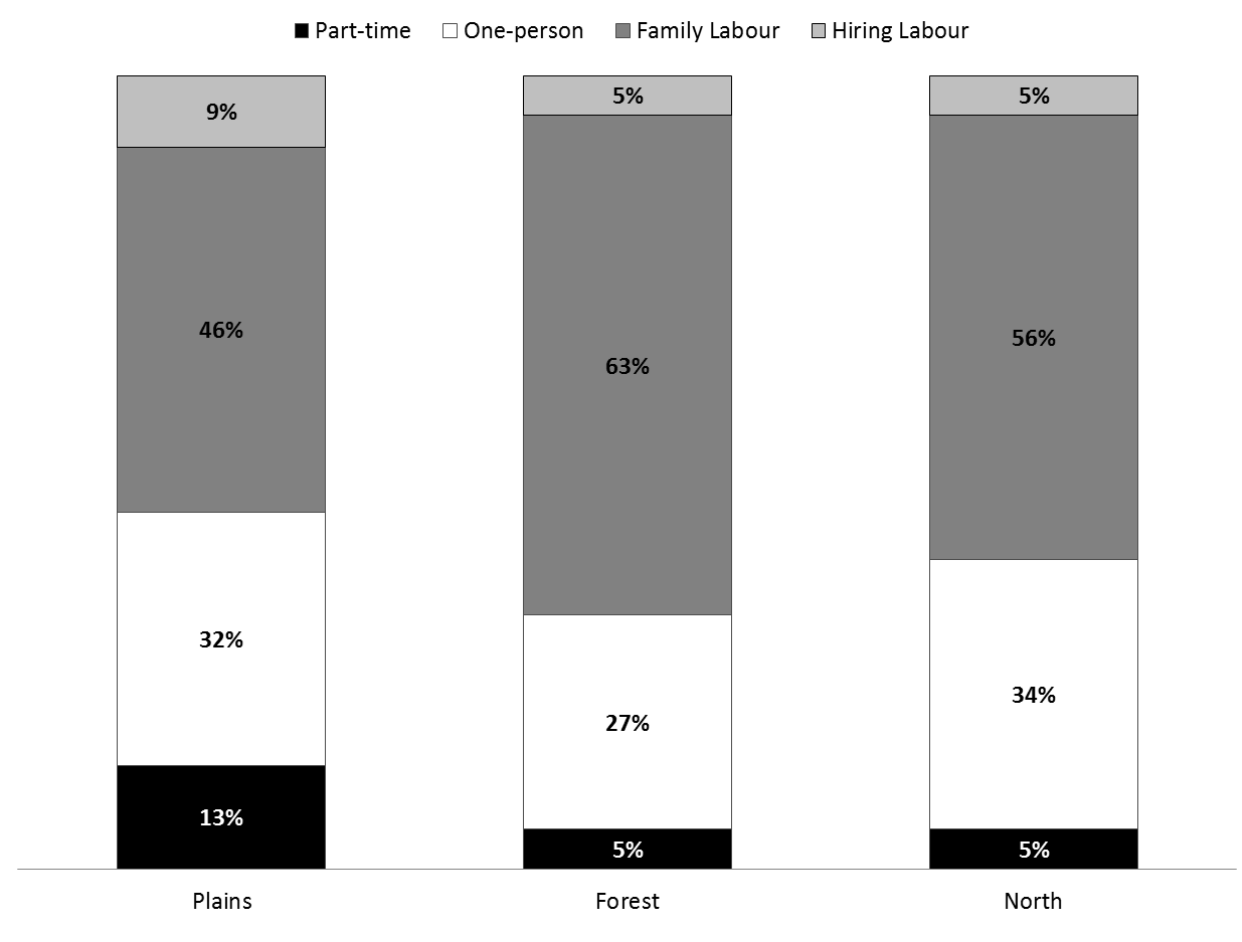

Figure 2. Proportion of farm types in different regions of Sweden

The hired labour input on HL farms accounted for, on average, $71.1 \%$ of the total labour input. The farmer accounted for $22.2 \%$ and the family $6.7 \%$ of the labour. This can be interpreted as indicating that these farms fall outside of the definition of the notional family farm, although the family labour mainly covers managerial work (Djurfeldt, 1996).

\subsection{Gendered time}

The dominance of men in agriculture was reflected in the FADN sample and is supported by official statistics (SCB, 2012). Of the farms in the sample, $86.4 \%$ were owned by men, $8.6 \%$ by corporations and $5 \%$ by women. Of the 26 female-owned farms in the sample, $65.4 \%$ were within group FL, 30.8\% in OP and 3.8\% in PT (Figure 3). There was no female-owned farm in group HL. Farms owned by men dominated all farm types, but the proportion was largest for PT (94.1\%). About two-thirds of the labour-hiring farms $(68.3 \%)$ were owned by men, while corporations owned the other one-third (31.7\%). Due to the small proportion of women, the comparative gender analysis primarily focused on the family labour farms. Of 
the 323 family labour farms in the sample, men owned $84.7 \%$, corporations $9 \%$ and women $6.3 \%$. The average age of the owner in this group was 50 years for women and 54 years for men. Half of the female-owned FL farms were located in the southern plains, $34.6 \%$ in the central forest regions and $15.4 \%$ in the northern regions. Almost two-thirds $(65.8 \%)$ of the male-owned FL farms were located in the southern plains, $23.6 \%$ in the central forest region and $10.6 \%$ in the northern region. There was a slight, although non-significant, difference in the geographical dimensions, with a higher proportion of male-owned farms in the south and female-owned farms in the central forest and northern regions - something that emphasises the interconnection between the spatial and temporal.

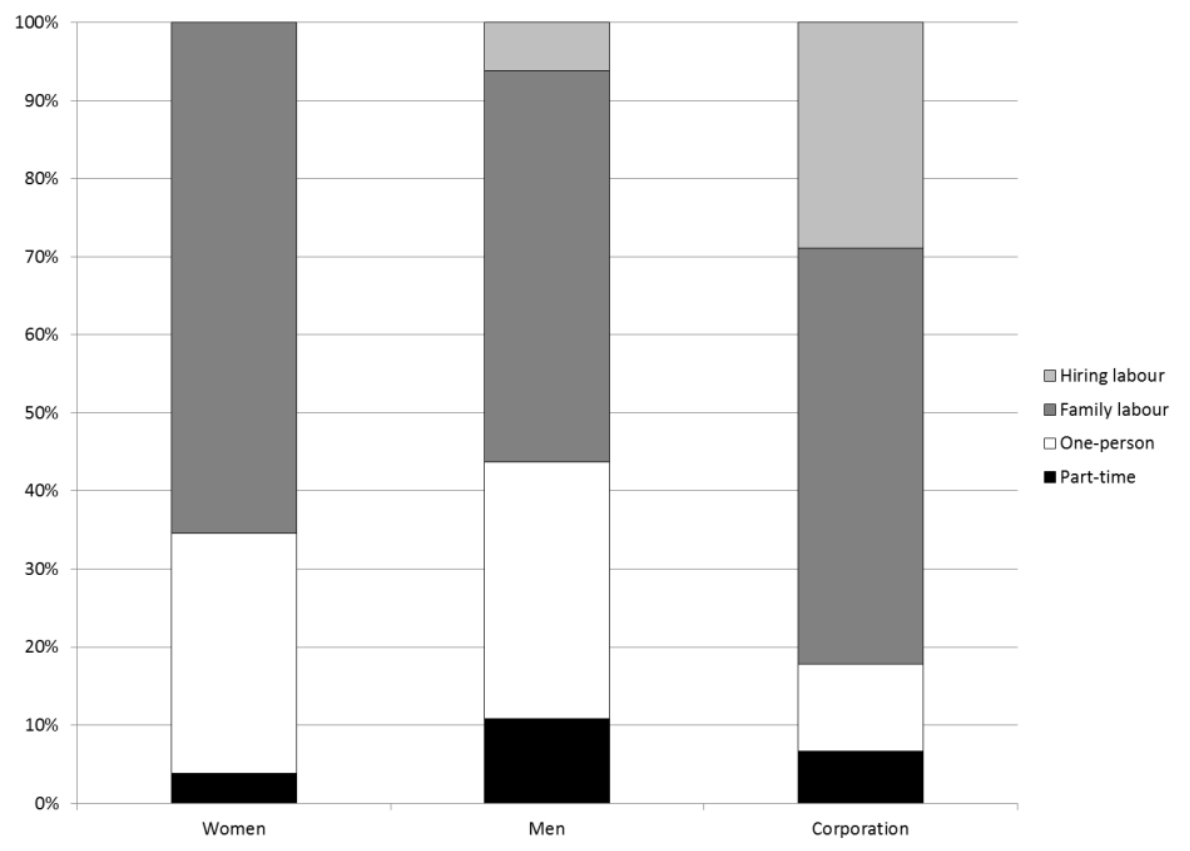

Figure 3. Proportion of farm types in the three owner groups

The input of labour by a spouse and other family members was significantly larger on female-owned farms than male-owned farms (39\% and 23\%) (Figure 4). The same applied for the group of one-person female-owned farms. Looking at the whole dataset, the input of labour by the husband on female-owned farms was significantly larger than the reverse $(\mathrm{p}<0.05)$. The input of hired labour (permanently employed) was significantly larger on male-owned farms than on female-owned farms $(\mathrm{p}<0.05)$, both in general and within group 
FL. This difference was larger in the plains and forest regions than in the northern region. Furthermore, none of the female-owned farms was dependent on hiring labour. Farm size, estimated by labour input, showed small differences between male-owned and femaleowned farms. This seems to indicate that the wives of male farmer-owners more often work off-farm and that their labour is to some extent replaced by hired workers. These different forms of temporalities in farms owned by men and women demonstrate the gendered time in the farm labour process.
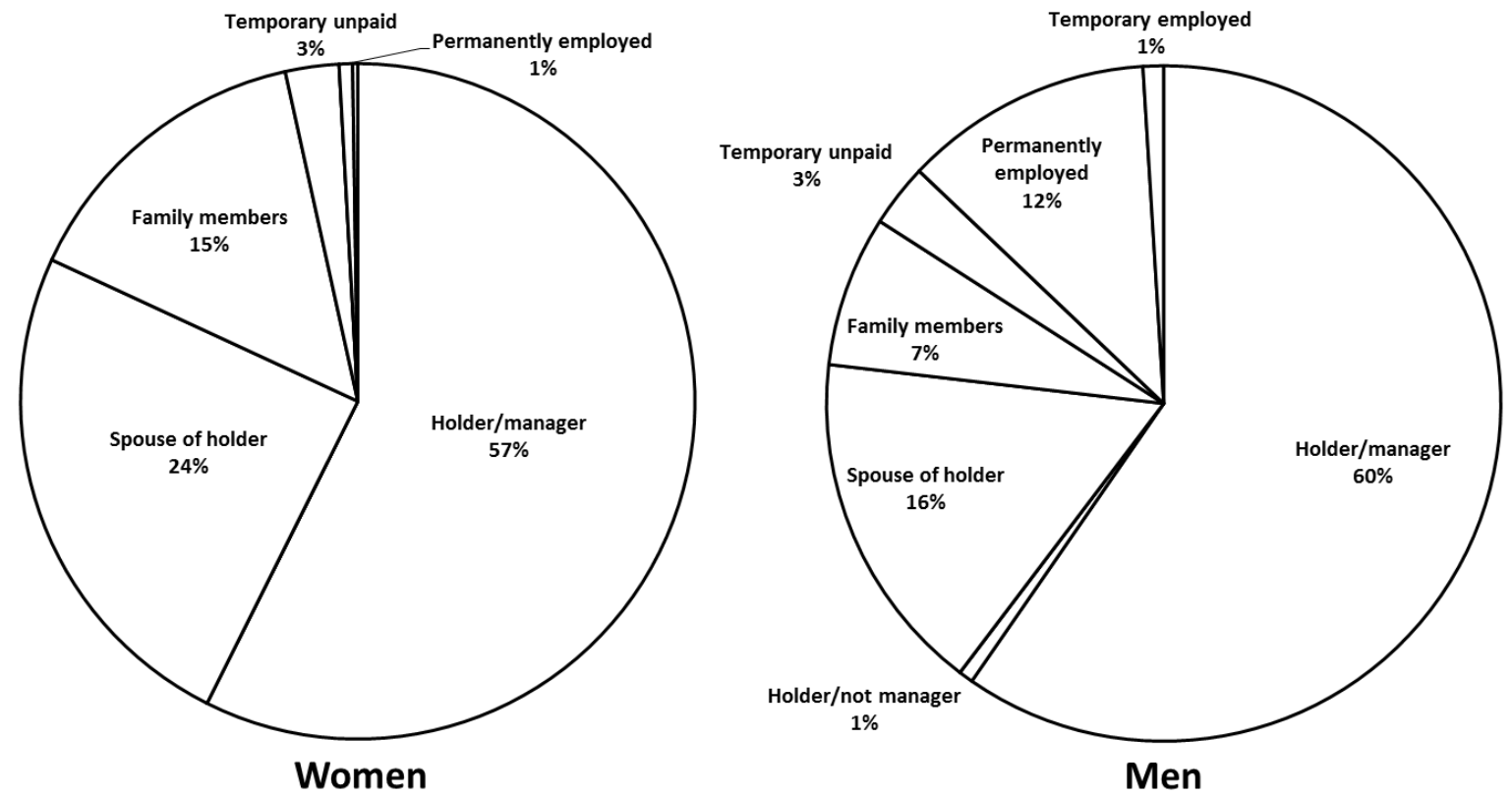

Figure 4. Average input of labour types in family labour farms held by women and men

Female-owned farms had a larger total labour input per hectare than male-owned farms, both in OP (70.5/41.2 h/ha) and FL (61.6/55.7 h/ha). This might indicate that women are engaged in more labour-intensive activities, or that their farms have a lower degree of mechanisation than those owned by men. This underlines the interconnection between other dimensions and different forms of temporality. All except one of the female-owned farms reared livestock, with cattle for milk and meat production as the dominant livestock type. Within the group of male-owned farms, about one-fifth $(21 \%)$ were specialist arable farms. Cattle farms were also the largest group of male-owned farms, but the proportion was 
smaller than for female-owned farms. More than $90 \%$ of the specialist arable farms were located in the plains region, where they accounted for $25.5 \%$ of the farms, emphasising the importance of place in the agro-ecological process. The demand for labour in livestock rearing was clearly visualised in relation to farm type. In the group of part-time farms, $36 \%$ of the businesses had livestock, but the proportion increased steadily in the other mainly family labour-based farm types: OP (75\%) and FL (93\%). Based on non-crop sales value, $75 \%$ of female-owned farms could be characterised as specialist livestock farms. The corresponding proportion within the group of male-owned farms was 50.5\%. The larger involvement in livestock-based production on farms owned by women could be one factor explaining the difference in labour input per hectare and the average larger acreage of maleowned farms (30 ha/54 ha). These factors emphasise the different temporalities of farms owned by women and men and their interconnection with property as an obstacle.

Estimated as a proportion of the total sales value, cow milk was the largest source of production income on both female- and male-owned farms. However, milk accounted for $66 \%$ of the total sales value for female-owned farms, but only $34 \%$ for male-owned farms. The proportional difference between cow milk and other branches was therefore much smaller in the group of male-owned farms (Figure 5). In relation to the proportion of livestock, this might indicate greater diversification on both group and farm level than on female-owned farms. The average sales value per hour of labour was 1.49 -fold larger on male-owned than on female-owned FL farms and 3.9-larger on male-owned than on femaleowned OP farms. The sales value in relation to arable acreage showed small differences between the farms. This indicates that the production on female-owned farms is more labour-demanding or that the products produced are less highly valued, both important factors in the various forms of temporalities. The results of the gender analysis, i.e. labour time per hectare, proportion of livestock farms and proportion of cow milk sales, might 
explain this difference. Thereby, the results also emphasise the gendered structure of time in agro-family-businesses. The sales values underline the importance of asking what the different labour is used for, linking the local organisation of the labour process to the national and global level through the market, disclosing the interconnection of various temporalities between different spheres and the gendered modes of intersections between time, value and economy - stressing the importance of the temporal perspective within family business research in general (cf. Sharma et al., 2014).
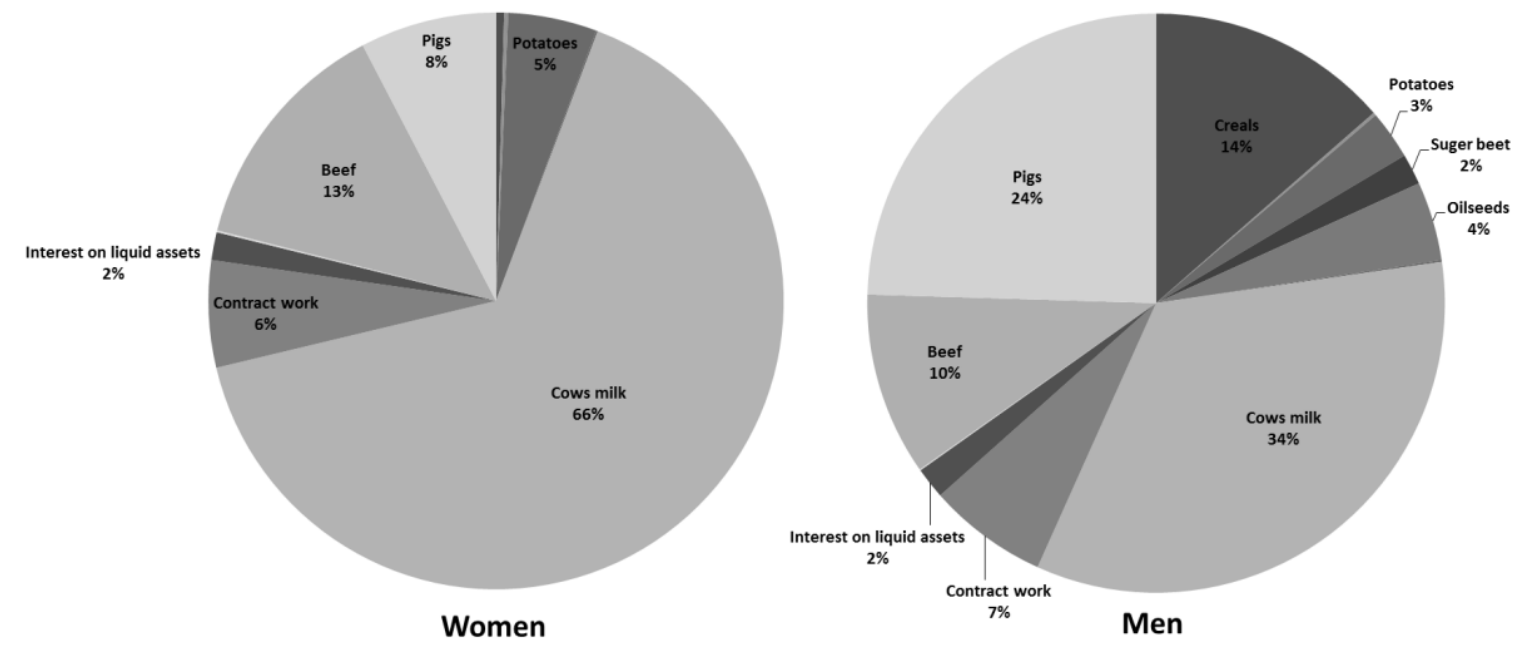

Figure 5. Proportion of main production activities on farms held by women and men

\section{CONCLUDING DISSCUSION}

In the introduction to this article, the importance of a situated discussion and study of the concept of family farming in a specific agrarian structure was emphasised. The primary purpose of the analysis was to increase understanding of the gendered position and relations of the farm labour process through a time-use study. Previous typological studies highlighted the difficulties in developing one universal definition of the family farm, with differing potentials and constraints depending on the context and the aspects of the agrarian structure being studied. This includes definition of the labour-use criterion. With the potential and limitations of the material, the typology of this study can be seen as a merged 
product of previous definitions by Hill (1993) and Djurfeldt (1996). Their work provided the theoretical tools and framework to capture and discuss different aspects of the Swedish agrarian structure. However, these definitions used here were adapted to the FADN data in order to better capture the relations and structures of the Swedish farm sector, to facilitate the study of the development over time and to allow comparative studies of family farming, the farm labour process and agrarian structures. The problematic aspects of non-context sensitive comparative studies within farming have been emphasised in the past (Blekesaune, 1996), but situated comparative studies are still fruitful in the process of understanding structural relations and identifying context-specific aspects. The criteria used and the availability of long-term data are important from a longer temporal perspective in order to monitor and analyse the changes and the transformations over time within the agrarian structure, the labour process and different organisations of labour and temporalities; e.g. to identify patterns of feminisation and masculinisation (cf. Bjørkhaug and Blekesaune, 2007). Operationalisation of the labour-use criteria to analyse the FADN data involved difficulties in classifying farms that deviated from the typical norm. The essential drawback with the criteria and the material was the inability to capture the interrelations between the farm and the household, both in terms of labour and income. This underlines the importance of the relationship between criteria and terminology. In this study, the farm types were defined by their total labour input and not by household income, resulting in some difficulties in distinguishing exactly between productive small farms, i.e. part-time and one-person farms. However, the material and the easily operationalised criteria were useful for capturing vital aspects of the agrarian realities and the development of the agrarian structure and labour process. A workable typology of both family farming and family businesses, in general, is crucial to assess the effects and structural implications of policy reforms. Depending on the aim and focus of policies, various criterions is needed. 
In comparison with Djurfeldt and Gooch (2002), the analysis illustrated the resilience of family farming and the stability of agrarian structures over the past two decades. The small differences compared with previous studies in the division of different farm types in the agrarian structure indicate that part-time and one-person farms have developed as a stable form of production over time. This confirms the link between the farm and the family in the farming sector (Djurfeldt and Waldenstrom, 1999). The dominance of family labour in the farm structure has clearly persisted, and there were even indications that its importance may have grown the last decades (cf. Bjørkhaug and Blekesaune, 2007). This study, together with others (Djurfeldt and Gooch, 2002, Hill, 1993), contradicts the claim by Errington and Gasson (1994) that "the use of family labour has become a less distinctive feature of farm organization in much of the world and therefore a less relevant criterion for defining the family farm" within the Swedish context. The increased proportion of family labour emphasises its flexibility as a non-fixed cost, an aspect overlooked by Errington and Gasson (1993, 1994).

A shift identified in relation to previous studies was the increased proportion of hiring labour farms (cf. Djurfeldt and Waldenström, 1996). This transformation over time of different temporalities further emphasises the need to investigate the "total social organisation of labour" (Glucksmann, 2005) within the agricultural sector and interrelations of work in different spheres. There were also small geographical differences in agrarian structure, underlining the spatial factor in agrarian studies of temporality. The largest differences were between the southern plains (the more productive area of Sweden) and the two other regions. The high proportion of PL, OL and HL farms in the plains region might indicate a more stratified agrarian structure, while FL farms occupied a more dominant position in the forest and northern regions. 
In comparison with previous studies (e.g. Djurfeldt and Gooch, 2002, Hill, 1993), this study identified a generally increasing proportion of family labour input, which could partly be interpreted as an effect of re-peasantisation/regrounding (Ploeg, 2008, Ploeg et al., 2012) and goes against the development in other contexts (cf. Pritchard et al., 2007). In the dataset used, this was mainly linked to a decrease in the use of additional hired labour in the dominant farm type; the family labour farm (cf. Thomas et al., 1996, Lyson and Guptill, 2004). In relation to hiring labour farms, the gap between labour hiring and family labour seems to have increased in recent decades (cf. Djurfeldt and Waldenström, 1996), partly owning to increased levels of rationalisation and mechanisation. Even though the more commercial focus of the material of this study, the trends of an increase dependence on family labour become even more significant. However, the increased proportion of hiring labour farms found here also indicated a slight stratification of the Swedish agricultural sector in terms of labour use and the various types of temporalities and the gendered notion of professionalism (cf. Bjørkhaug and Blekesaune, 2007). In the process of repeasantisation, the organisation of farm production and the labour process in a way that minimises or even eliminates hiring labour can be seen as an act to fight dependency (Ploeg, 2008).

The gender analysis showed small differences in the labour input of female and male farm owners, as well as in farm size estimated on labour input. However, in relation to the arable acreage of the farm, female-owned OP and FL farms had a larger total labour input per hectare than the male-owned counterparts. Almost all female-owned farms had livestock, while $20 \%$ of male-owned had no livestock. This gender difference also arose in the sale value per labour hour, with male-owned farms having almost 1.5 -fold larger value per hour than female-owned farms. Production income was more equally distributed between enterprises within the group of male-owned farms, while production income on female- 
owned farms was clearly dominated by cow milk. These results indicate that the gender differences in temporalities are a consequence of production on female-owned farms being more labour-demanding and the products produced being less highly valued. This emphasises the stratified value of time and also what different types of labour are used for in the "total social organisation of labour".

The analysis showed a significant difference between female-owned and male-owned farms in the use of labour from the spouse and other family members, with indications that female-owned farms are more dependent on family members and farm in partnership. This indicate men's specialisation in farm work and women's "need to negotiate many obstacles before choosing a farming profession" (Bjørkhaug and Blekesaune, 2007). This can be driven by a difference in forms of temporalities, i.e. domestic labour, with men primarily stepping in on the farm rather in the household to assist their partners. Similar differences have been identified within the Norwegian farm sector (Bjørkhaug and Blekesaune, 2008). The significant gender difference in the use of hiring labour can also be interpreted as disclosing the temporalities of the farm, i.e. the mainly invisible domestic labour of women and their off-farm labour. This quantitative time-use study based on FADN tended to misrepresent the value of women's domestic and caring responsibilities and could be regarded as a way of inserting women into male time. Although there are problems involved in time-use studies, this type of research should not be abandoned or its findings disregarded (Bryson, 2008). The present study identified ways to improve time-use and labour-use studies in general and FADN in particular. With its clear policy aim and purpose, FADN constitutes an important source of empirical data for studies working from an agrarian sociological and policy perspective. This study demonstrated the potential fruitfulness of the material when combined with a labour-use typology. Exploration of the concept of family farming using this dataset provided a basis for dismantling the 'myth' of the family farm in 
these structures (Hill, 1993, Vogeler, 1981, Hedley, 1982) and for recognising the diversity of the farming sector. However, it is critical to devote attention to the process of FADN itself and not only to study the implications and effects of policies on the agrarian sector without acknowledging and exploring the limitations of the material on a European, national and regional level. Thereby, this study challenges the gender neutrality of family business policy in general and agricultural policy in particular. The necessity to further explore family businesses in various sectors, localities and structures of Sweden is also emphasised (cf. Bjuggren et al., 2011)

While different typologies of family farming capture different aspects of agrarian realties, the labour use-criterion constitutes the strongest methodology to study the exploitation of the farm labour process and the agrarian structure. This study highlighted the necessity of exploring the family farm concept and the various types of temporalities within the Swedish context, both from a sociological and a policy perspective, in order to increase the understanding of the gendered positions, social relations in farming and the interrelation of work in different spheres. This study provides important insights to the social relations of agrarian processes through the interlinkages between gender, economy, time materiality and geography. This is done by situating the analysis of the structuring of time in the social and material relations of Swedish agrarian sector and policy. The results showed that it is possible to develop a workable and fruitful typology of the agrarian structure and use it to analyse the gendered farm labour process, enabling comparative studies of the Swedish agrarian sector in the future. Although the political aim and ambitions, this study present evidence of a delay in the development of gender equality in Swedish agriculture, in particular on farm household level. 


\section{REFERENCES}

Astrachan, J. H.and Shanker, M. C. (2003), "Family Businesses' Contribution to the U.S. Economy: A Closer Look". Family Business Review, Vol. 16 No. 3, pp. 211-219.

Bailey, W. R. (1973), The One-Man Farm, United States Department of Agriculture, Washington DC.

Bennett, J. W., Kohl, S. B.and Binion, G. (1982), Of time and the enterprise : north American family farm management in a context of resource marginality : based on a decade of research in the province of Saskatchewan, Canada, University of Minnesota Press, Minneapolis.

Bernstein, H. (2010), Class dynamics of agrarian change, Fernwood Pub., Halifax, N.S.

Bjuggren, C. M., Johansson, D.and Sjögren, H. (2011), "A Note on Employment and Gross Domestic Product in Swedish Family-Owned Businesses: A Descriptive Analysis". Family Business Review, Vol. No., pp.

Bjørkhaug, H.and Blekesaune, A. (2007), "Masculinisation or Professionalisation of Norwegian Farm Work: A Gender Neutral Division of Work on Norwegian Family Farms?". Journal of Comparative Family Studies, Vol. 38 No. 3, pp. 423-434.

Bjørkhaug, H.and Blekesaune, A. (2008), "Gender and Work in Norwegian Family Farm Businesses". Sociologia Ruralis, Vol. 48 No. 2, pp. 152-165.

Blekesaune, A. (1996), Family farming in Norway: An analysis of structural changes within farm households between 1975 and 1990, Department of Sociology and Political Science, Trondheim.

Blekesaune, A.and Haugen, M. S. (2002). "Landbrukskvinners bidrag til husholdets leve kår - arbeid og inntekt $\mathrm{i}$ et komparativt perspektiv $=$ [Farm women's contribution to households'living conditions, work and income in a comparative perspective] ". in Almås, R., Haugen, M. S. \& Johnsen, J. P. (Ed.) Bygdeforskning gjennom 20 år. Tapir Academic Publishing, Trondheim, pp. 141-154.

Brandth, B. (2002), "Gender Identity in European Family Farming: A Literature Review". Sociologia Ruralis, Vol. 42 No. 3, pp. 181-200.

Bryson, V. (2008), "Time-Use Studies". International Feminist Journal of Politics, Vol. 10 No. 2, pp. 135-153.

Buttel, F. H. (1983). "Beyond the Family Farm". in Wilkening, E. A. \& Summers, G. F. (Ed.) Technology and social change in rural areas : a Festschrift for Eugene A. Wilkening. Westview Press, Boulder, Colo., pp. 87-107.

Buttel, F. H. (1996). "Theoretical issues in global agri-food restructuring". in Burch, D., Rickson, R. E. \& Lawrence, G. (Ed.) Globalization and agri-food restructuring : perspectives from the Australasia region. Avebury, Aldershot, pp. 17-44.

Bäck-Wiklund, M.and Lindfors, H. (1990), Landsbygd, livsform och samhällsförändring = [Countryside, life mode and societal change] Daidalos, Göteborg.

Calus, M.and Huylenbroeck, G. V. (2010), "The Persistence of Family Farming: A Review of Explanatory Socio-economic and Historical Factors". Journal of Comparative Family Studies, Vol. 41 No. 5, pp. 639-660.

Ciaian, P., Kancs, d. A.and Swinnen, J. F. M. (2010), EU land markets and the Common Agricultural Policy, Centre for European Policy Studies, Brussels.

Djurfeldt, G. (1981), "What Happened to the Agrarian Bourgeoisie and Rural Proletariat under Monopoly Capitalism? Some Hypotheses Derived from the Classics of Marxism on the Agrarian Question". Acta Sociologica, Vol. 24 No. 3, pp. 167-191.

Djurfeldt, G. (1990), "More one-man farms and part-time employment - production forms in Swedish agriculture". Sociologisk Forskning, Vol. 27 No. 2, pp. 2-21. 
Djurfeldt, G. (1994), Gods och gårdar : jordbruket $i$ sociologiskt perspektiv $=$ [Estates and farmsteads : agriculture in sociological perspective], Arkiv, Lund.

Djurfeldt, G. (1996), "Defining and Operationalizing Family Farming from a Sociological Perspective". Sociologia Ruralis, Vol. 36 No. 3, pp. 340-351.

Djurfeldt, G.and Gooch, P. (2002), "Farm Crisis, Mobility and Structural Change in Swedish Agriculture, 1992-2000". Acta Sociologica, Vol. 45 No. 2, pp. 75-88.

Djurfeldt, G.and Waldenstrom, C. (1999), "Mobility patterns of Swedish farming households". Journal of Rural Studies, Vol. 15 No. 3, pp. 331-344.

Djurfeldt, G.and Waldenström, C. (1996), "Towards a Theoretically Grounded Typology of Farms: A Swedish Case". Acta Sociologica, Vol. 39 No. 2, pp. 187-210.

Ds (2004), Det går långsamt fram: jämställdheten inom jord- och skogsbrukssektorn = [Moving forward slowly: gender equality in agricultural and forestry sector] (Ds 2004:39), Ministry of Agriculture, Government Offices of Sweden, Stockholm.

EC (2013a), About FADN - Sample selection, European Commission, available at:, http://ec.europa.eu/agriculture/rica/methodology2_en.cfm (accessed May 23, 2013).

EC (2013b), About FADN - Swedish Region Codes, European Commission, available at:, http://ec.europa.eu/agriculture/rica/regioncodes_en.cfm?CodeCountry=SVE (accessed January 28, 2013).

Errington, A.and Gasson, R. (1994), "Labour use in the farm family business". Sociologia Ruralis, Vol. 34 No. 4, pp. 293-307.

Eurostat (2012), Labour costs in the EU27 in 2011, Eurostat Press Office, Eurostat newsrelease.

Flygare, I. (1999), Generation och kontinuitet : familjejordbruket i två svenska slättbygder under 1900-talet $=$ [Generations and continuity : family farming in two Swedish grain-growing districts in the 20th century], Upplands fornminnesfören. och hembygdsförb., Uppsala.

Flygare, I. (2001). "Länkar, agenter och alternativ : kvinnogenerationer i 1900-talets jordbruk $=[$ Links, agents and alternatives : generations of women in twentieth century agriculture]". in Liljewall, B., Niskanen, K. \& Sjöberg, M. (Ed.) Kvinnor och jord. Nordiska museets förlag, Stockholm, pp. 13-30.

Flygare, I. (2008). "Det bekönade fältet - Kvinnors jordbruksarbete i politisk retorik och vardaglig praktik $=[$ The gendered field - Women's agricultural labour in political rhetoric and everbyday practice] ". in Isacson, M. \& Houltz, A. (Ed.) Arbete pågår : i tankens mönster och kroppens miljöer. Acta Universitatis Upsaliensis, Uppsala, pp. $219-235$.

Flygare, I. (2011). "Svenska småbruk: ett bestående inslag i landsbyggden $=[$ Swedeish small-holders: a persistent feature of the rural]". in Antonson, H. \& Jansson, U. (Ed.) Jordbruk och skogsbruk $i$ Sverige sedan år 1900 : studier av de areella näringarnas geografi och historia. Kungl. Skogs- och lantbruksakademien, Stockholm, pp. 7087.

Flygare, I.and Isacson, M. (2011). "The tension between modernity and reality: 1945-2010". in Myrdal, J. \& Morell, M. (Ed.) The agrarian history of Sweden: from 4000 BC to $A D$ 2000. Nordic Academic Press, Lund, pp. 214-256.

Forsberg, G. (2005). "Structural Funds and Gender Mainstreaming: Counting heads or changing structures?". in Schmied, D. (ed.) Winning and losing : the changing geography of Europe's rural areas. Ashgate, Aldershot, UK, pp. 203-215.

Friedmann, H. (1986a). "Family enterprises in agriculture: structural limits and political possibilities". in Cox, G., Lowe, P. \& Winter, M. (Ed.) Agriculture : people and policies. Allen \& Unwin, London, pp. 41-60. 
Friedmann, H. (1986b), "Patriarchy and Property". Sociologia Ruralis, Vol. 26 No. 2, pp. 186-193.

Gasson, R.and Errington, A. (1993), The farm family business, CAB International, Wallingford.

Gezelius, S. S. (2014), "Exchange and Social Structure in Norwegian Agricultural Communities: How Farmers Acquire Labour and Capital". Sociologia Ruralis, Vol. 54 No. 2, pp. 206-226.

Glucksmann, M. (1998), "'What a Difference a Day Makes': A Theoretical and Historical Exploration of Temporality and Gender". Sociology, Vol. 32 No. 2, pp. 239-258.

Glucksmann, M. (2000), Cottons and casuals : the gendered organisation of labour in time and space, Sociologypress, Durham.

Glucksmann, M. (2005), "Shifting boundaries and interconnections: Extending the 'total social organisation of labour'". The Sociological Review, Vol. 53 No. 2, pp. 19-36.

Hansen, K. (2006), "Skånska fideikommiss: Studie av de skånska fideikommissens bildande 1725-1800 = [Entailed estates in Skåne: a study of the entailed estates in Skåne 1725-1800]". Ale. Historisk tidskrift för Skåne, Blekinge och Halland, Vol. No. 1, pp. 12-36.

Harvey, D. (1990), "Between Space and Time: Reflections on the Geographical Imagination". Annals of the Association of American Geographers, Vol. 80 No. 3, pp. 418-434.

Hedley, M. J. (1982), "'Normal expectations': rural women without property". Resources for Feminist Research, Vol. 11 No. 1, pp. 15.

Henrekson, M. (2005), "Entrepreneurship: a weak link in the welfare state?". Industrial and Corporate Change, Vol. 14 No. 3, pp. 437-467.

Hill, B. (1993), "The 'myth' of the family farm: Defining the family farm and assessing its importance in the European community". Journal of Rural Studies, Vol. 9 No. 4, pp. 359-370.

Hochschild, A.and Machung, A. (1989), The second shift : working parents and the revolution at home, Viking, New York, N.Y.

Hoyle, R. W., Bavel, B. J. P. v.and Brakensiek, S. (2010), Rural Economy and Society in North-Western Europe, 500-2000 - Social relations : property and power, Brepols Publishers, Turnhout.

Jervell, A. M.and Løyland, J. (1998), "Endringer i jordbrukshusholdenes inntekter 1986-96 $=[$ Changes in the income of farm households 1986-96]". Landbruks $\phi$ konomisk forum, Vol. 98 No. 4, pp. 63-75.

Johnsen, S. (2004), "The redefinition of family farming: agricultural restructuring and farm adjustment in Waihemo, New Zealand". Journal of Rural Studies, Vol. 20 No. 4, pp. 419-432.

Kelly, R.and Shortall, S. (2002), "'Farmers' wives': women who are off-farm breadwinners and the implications for on-farm gender relations". Journal of Sociology, Vol. 38 No. 4, pp. 327-343.

Kinsella, J., Wilson, S., De Jong, F.and Renting, H. (2000), "Pluriactivity as a Livelihood Strategy in Irish Farm Households and its Role in Rural Development". Sociologia Ruralis, Vol. 40 No. 4, pp. 481-496.

Lenin, V. I. (1946), Capitalism in agriculture, International Publishers, New York.

Lidestav, G. (2010), "In competition with a brother: Women's inheritance positions in contemporary Swedish family forestry". Scandinavian Journal of Forest Research, Vol. 25 No. 9, pp. 14-24. 
Lindbeck, A. (1997), "The Swedish Experiment". Journal of Economic Literature, Vol. 35 No. 3, pp. 1273-1319.

Lobao, L.and Meyer, K. (2001), "The Great Agricultural Transition: Crisis, Change, and Social Consequences of Twentieth Century US Farming". Annual Review of Sociology, Vol. 27 No., pp. 103-124.

Long, N. (1986). "Commoditization: thesis and antithesis". in Long, N., van der Ploeg, J. D., Curtin, C. \& Box, L. (Ed.) The commoditization debate : labour process, strategy and social network. Agricultural University Wageningen, Wageningen, pp. 1-25.

LSR (1988), Deltidslantbrukets struktur och betydelse : delrapport från projekt utfört av Lantbruksstyrelsen och SCB på uppdrag av Lantbruksekonomiska samarbetsnämndens rationaliseringsgrupp $=$ [The structure and importance of parttime farming: interim from a project carried out by agricultural board and Statistics Sweden on behalf of the rationalisation group of the agricultural comic co-operation committee], Swedish University of Agricultural Sciences, Uppsala.

Lundqvist, P., Stål, M.and Pinzke, S. (1997), "Ergonomics of Cow Milking in Sweden". Journal of Agromedicine, Vol. 4 No. 1-2, pp. 169-176.

Lyson, T. A.and Guptill, A. (2004), "Commodity Agriculture, Civic Agriculture and the Future of U.S. Farming*". Rural Sociology, Vol. 69 No. 3, pp. 370-385.

Lyson, T. A., Torres, R. J.and Welsh, R. (2001), "Scale of Agricultural Production, Civic Engagement, and Community Welfare". Social Forces, Vol. 80 No. 1, pp. 311-327.

MacDonald, R., Shildrick, T., Webster, C.and Simpson, D. (2005), "Growing Up in Poor Neighbourhoods: The Significance of Class and Place in the Extended Transitions of 'Socially Excluded'Young Adults". Sociology, Vol. 39 No. 5, pp. 873-891.

Maskell, P. (2001a), Innovation and learning for competitiveness and regional growth - a policy challenge, Nordregio, Stockholm.

Maskell, P. (2001b). "Knowledge creation and diffusion in geographic clusters: Regional development implications". in Felsenstein, D. (ed.) Public investment and regional economic development. Edward Elgar, Cheltenham, pp. 59-74.

Morell, M. (2011a). "Agriculture in industrial society : 1870-1945". in Myrdal, J. \& Morell, M. (Ed.) The agrarian history of Sweden : from 4000 BC to AD 2000. Nordic Academic Press, Lund, pp. 165-213.

Morell, M. (2011b). "Böndernas jord: äga eller arrendera, ärva eller köpa = [The farmers' land: to own or rent, inherit or buy]". in Antonson, H. \& Jansson, U. (Ed.) Jordbruk och skogsbruk i Sverige sedan år 1900 : studier av de areella näringarnas geografi och historia. Kungl. Skogs- och lantbruksakademien, Stockholm, pp.

Morell, M.and Olsson, M. (2010). "Scandinavia 1750-2000". in Hoyle, R. W., Bavel, B. J. P. v. \& Brakensiek, S. (Ed.) Rural Economy and Society in North-Western Europe, 500-2000 - Social relations : property and power. Brepols Publishers, Turnhout, pp. 314-347.

Moxnes Jervell, A. (1999), "Changing Patterns of Family Farming and Pluriactivity". Sociologia Ruralis, Vol. 39 No. 1, pp. 110-116.

NS (2013), Agriculture in the United Kingdom 2012, National Statistics London.

OECD (2016), Agricultural land, OECD Data, available at:, https://data.oecd.org/agrland/agricultural-land (accessed January 14, 2016).

Olsson, M. (2002), Storgodsdrift : godsekonomi och arbetsorganisation i Skåne från dansk tid till mitten av 1800-talet = [Large estate production: estate economy and labour organisation in Skane from danish time until the mid nineteenth century], Almqvist \& Wiksell International, Stockholm. 
Pini, B.and Leach, B. (2011), Reshaping gender and class in rural spaces, Ashgate, Burlington.

Ploeg, J. D. v. d. (2008), The new peasantries: struggles for autonomy and sustainability in an era of empire and globalization, Earthscan, London.

Ploeg, J. D. v. d., Jingzhong, Y.and Schneider, S. (2012), "Rural development through the construction of new, nested, markets: comparative perspectives from China, Brazil and the European Union". The Journal of Peasant Studies, Vol. 39 No. 1, pp. 133173.

Pritchard, B., Burch, D.and Lawrence, G. (2007), "Neither 'family' nor 'corporate' farming: Australian tomato growers as farm family entrepreneurs". Journal of Rural Studies, Vol. 23 No. 1, pp. 75-87.

Reimer, B. (1986), "Women as farm labor". Rural sociology, Vol. 51 No. 2, pp. 143-155.

Rydén, R. (2004), Jordbrukarnas kooperativa föreningar och intresseorganisationer $i$ ett historiskt perspektiv $=[$ Farmers cooperative associations and interest oraganizations from a historical perspective], Kungl. Skogs- och lantbruksakademien, Stockholm.

SCB (2010), Jordbruksstatistisk årsbok: med data om livsmedel. $2010=$ [Yearbook of Agricultural statistics : including food statistics], Statistics Sweden, Stockholm.

SCB (2011a), Jordbruket i siffror: åren 1866-2007 = [Agriculture in figures years 18662007], Swedish Board of Agriculture, Jönköping.

SCB (2011b), Jordbruket i siffror: åren 1866-2007: Tabellbilaga = [Agriculture in figures years 1866-2007: Table appendix], Swedish Board of Agriculture, Jönköping.

SCB 2011c. Priser på jordbruksmark 2011 = [Agricultural land prices 2011]. Stockholm: Statistics Sweden.

SCB (2012), På tal om kvinnor och män: lathund om jämställdhet = [Speaking of women and men: crib on gender equality], Statistics Sweden, Stockholm.

SFS (1979), Land Acquisition Act (1979:230), Government Offices of Sweden, Stockholm.

Sharma, P. (2004), "An Overview of the Field of Family Business Studies: Current Status and Directions for the Future". Family Business Review, Vol. 17 No. 1, pp. 1-36.

Sharma, P., Salvato, C.and Reay, T. (2014), "Temporal Dimensions of Family Enterprise Research". Family Business Review, Vol. 27 No. 1, pp. 10-19.

SJV (2013), Jordbruksstatistisk årsbok : med data om livsmedel $2013=$ [Yearbook of Agricultural Statistics 2013 including Food Statistics], Statistics Sweden, Stockholm.

SKS (2013), Skogsstatistisk årsbok = [ Statistical yearbook of forestry], Swedish Forest Agency, Jönköping.

SOU (1995), Avbytarverksamhetens organisation och finansiering: betänkande $=$ [The organisation and funding of relief labour: report], Fritze, Stockholm.

Thomas, J. K., Howell, F. M., Wang, G.and Albrecht, D. E. (1996), "Visualizing Trends in the Structure of U.S. Agriculture, 1982 to 19921". Rural Sociology, Vol. 61 No. 2, pp. 349-374.

USDA (2011), Farms, Land in Farms, and Livestock Operations: 2010 Summary, United States Department of Agriculture, National Agricultural Statistics Service.

WB (2016), Agriculture, value added (\% of GDP), The World Bank, available at:, http://data.worldbank.org/indicator/nv.agr.totl.zs (accessed January 14, 2016).

Welsh, R. (2009), "Farm and market structure, industrial regulation and rural community welfare: conceptual and methodological issues". Agriculture and Human Values, Vol. 26 No. 1-2, pp. 21-28. 
Whatmore, S. (1991), Farming women: gender, work and family enterprise, Macmillan, Basingstoke.

Vogeler, I. (1981), The myth of the family farm : agribusiness dominance of U.S. agriculture, Westview press, Boulder, Colo. 